\title{
Sleep and Circadian Rhythms in the ICU
}

Editor

VIPIN MALIK

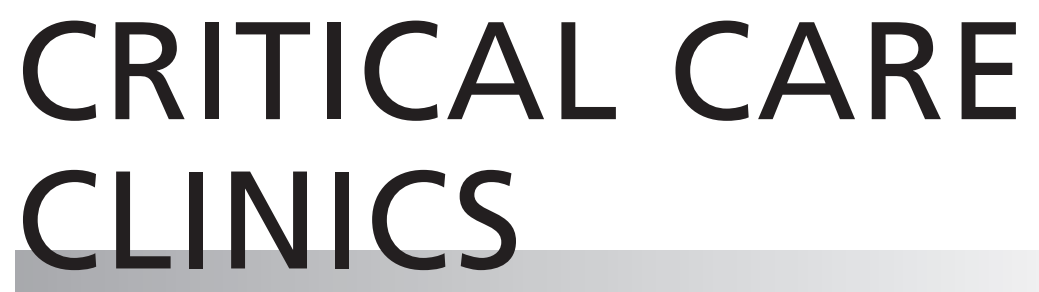

www.criticalcare.theclinics.com

Consulting Editor

RICHARD W. CARLSON

July 2015 • Volume 31 - Number 3 